\title{
Differences Between the Effects of Adrenaline and Noradrenaline on Insulin Secretion in the Dog
}

\author{
G. Ribes, J.P. Blayac and M. M. Loubatieres-Mariani \\ Laboratoire de Pharmacologie et Pharmacodynamie, Equipe de Recherche Associée au CNRS n 786, Institut de Biologie, Montpellier, France
}

\begin{abstract}
Summary. The effects of adrenaline and noradrenaline infusions on pancreaticoduodenal venous insulin output were studied in anaesthetized normal dogs. Two experimental protocols were used. In the first, the dogs had a normal blood glucose level at the start of the catecholamine infusion (normoglycaemic dogs). In the second, the animals were made hyperglycaemic by a continuous glucose infusion (hyperglycaemic dogs). In the normoglycaemic dogs, adrenaline $\left(0.5 \mu \mathrm{g} \cdot \mathrm{kg}^{-1}\right.$. $\mathrm{min}^{-1}$ ) provoked hyperglycaemia accompanied by an increase in insulin output. Noradrenaline $\left(0.5 \mu \mathrm{g} \cdot \mathrm{kg}^{-1} \cdot \mathrm{min}^{-1}\right)$ also caused an increase in insulin output but without any significant change in blood glucose. In hyperglycaemic dogs, adren-
\end{abstract}

aline $\left(2 \mu \mathrm{g} \cdot \mathrm{kg}^{-1} \cdot \mathrm{min}^{-1}\right)$ reduced the insulin response and enhanced the hyperglycaemia; noradrenaline $\left(2 \mu \mathrm{g} \cdot \mathrm{kg}^{-1}\right.$. $\min ^{-1}$ ) markedly increased the insulin response $(+2250 \%)$ without any significant change in blood glucose. Propranolol $(0.3 \mathrm{mg} / \mathrm{kg}$, IV) prevented the increase of insulin induced by noradrenaline. These findings show that, in the normal dog, adrenaline and noradrenaline infusions can produce opposite effects on insulin response depending on the experimental conditions.

Key words: Insulin secretion, adrenaline, noradrenaline, catecholamines, dog, blood glucose, propranolol.
It is generally accepted that adrenaline and noradrenaline inhibit insulin secretion $[2,8-10,15,16]$. Previous studies from this laboratory have shown that these two catecholamines inhibit insulin secretion from the isolated perfused rat pancreas [5]. However, in experiments performed on the isolated perfused pancreas in vitro, we observed that the B cell response to adrenaline showed great variation depending on the species (rat or $\mathrm{dog}$ ) and the concentration used [6]. More recently, we have shown that the perfusion of low dose adrenaline $\left(0.1 \mu \mathrm{g} \cdot \mathrm{kg}^{-1} \cdot \mathrm{min}^{-1}\right)$ in the dog induced an increase in insulin secretion without any significant increase of blood glucose level [7].

The aim of this work was to investigate whether there were differences between the effects of adrenaline and noradrenaline on insulin secretion in the dog. The study was performed using these agents at various doses, firstly in animals in normal basal conditions and then in animals whose insulin secretion was stimulated by hyperglycaemia induced by glucose infusion.

\section{Materials and Methods}

\section{Experimental Conditions and Methods}

Our experiments were carried out on normal male mongrel dogs weighing $16-20 \mathrm{~kg}$. After an $18-\mathrm{h}$ fast, the animals were anaesthetized with pentobarbital $(30 \mathrm{mg} / \mathrm{kg}$, IV). After a median laparotomy, a Tshaped catheter was inserted into the pancreaticoduodenal vein sectioned close to its junction with the portal vein. The animals were then given heparin $(5 \mathrm{mg} / \mathrm{kg}$, IV). Venous blood samples for insulin assay were taken from the T-shaped catheter. The blood glucose level from a peripheral vein was continuously recorded with a Technicon autoanalyser using the potassium ferricyanide procedure for haemolyzed blood [1]. Insulin was assayed in the plasma according to the radioimmunological B method of Hales and Randle [3], using pure dog insulin as standards. The anti-insulin antibody was INSIK-1 from C.E.A. (Commissariat à l'Energie Atomique, Gif-sur-Yvette, France). The sensitivity of this assay is $2 \mathrm{mU} / 1$ (crossreactivities: proinsulin $7 \%, \mathrm{C}$ peptide $\ll 0.01 \%$ ). The coefficients of variation were $9 \%$ (intra-assay) and $13.5 \%$ (inter-assay). Insulin output rate in the pancreaticoduodenal vein was determined by multiplying the concentration of insulin $(\mathrm{mU} / \mathrm{l})$ by the venous blood flow $(\mathrm{ml} / \mathrm{min})$ corrected by the haematocrit. Venous blood flow was measured by collecting the blood coming directly from the pancreas through the perpendicular part of the $T$-shaped catheter. For this purpose, the clamp was taken off and the blood stream towards the portal vein was clamped. Blood was collected in a graduated tube during a definite time. Femoral arterial blood pressure was continuously recorded by a Ludwig's manometer.

\section{Experimental Procedures}

Two experimental protocols were used: (1) the effects of the catecholamines were studied under normal conditions with a normal basal fasting blood glucose (normoglycaemic dogs); (2) the same experiments were performed in dogs with high blood glucose levels from a continuous infusion of glucose throughout the experiment (hyperglycaemic dogs). Glucose was infused at a rate of $1 \mathrm{~g} \cdot \mathrm{kg}^{-1} \cdot \mathrm{h}^{-1}$ for $30 \mathrm{~min}$, then at $0.5 \mathrm{~g} \cdot \mathrm{kg}^{-1} \cdot \mathrm{h}^{-1}$ for $2 \frac{1}{2} \mathrm{~h}$. Such an infusion produced a hyperglycaemic plateau after $30 \mathrm{~min}$. 


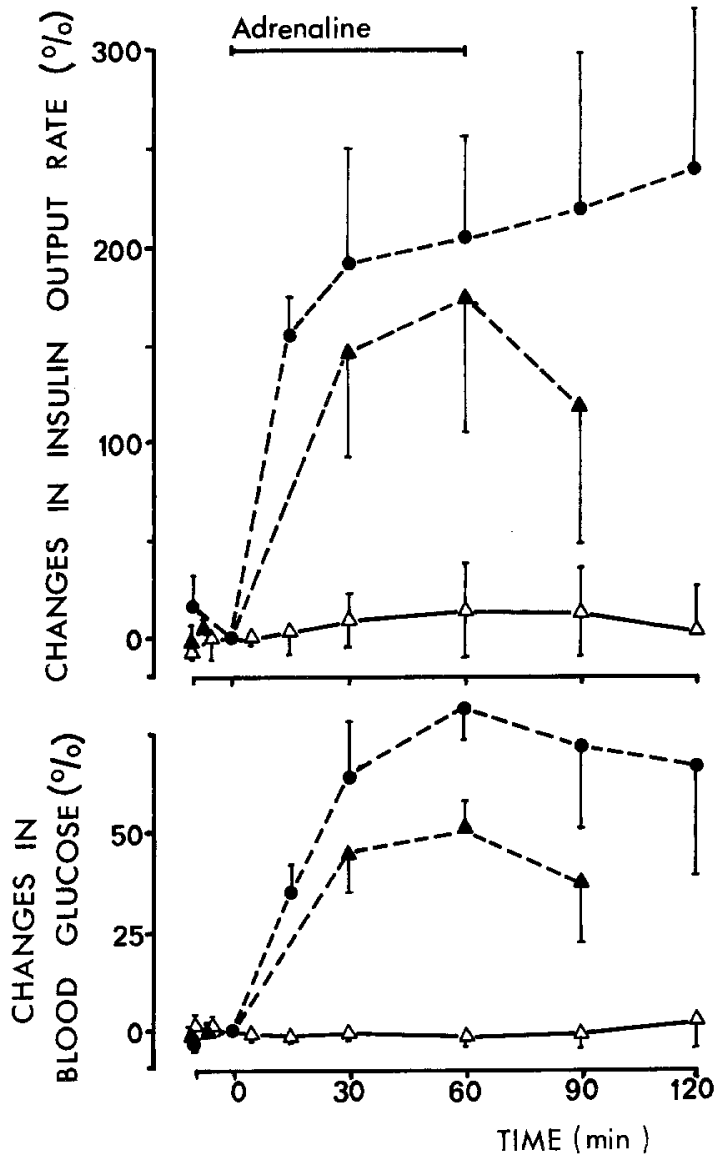

Fig. 1. Changes in plasma pancreaticoduodenal insulin output rate and in blood glucose in normoglycaemic dogs after adrenaline infusions at the doses of $0.01 \mu \mathrm{g} \cdot \mathrm{kg}^{-1} \cdot \min ^{-1}(\triangle \longrightarrow \Delta, n=4)$; $0.5 \mu \mathrm{g} \cdot \mathrm{kg}^{-1} \cdot \min ^{-1}(\boldsymbol{\Lambda}-\cdots-\boldsymbol{\Lambda}, n=7)$ and $1 \mu \mathrm{g} \cdot \mathrm{kg}^{-1} \cdot \min ^{-1}(\mathbf{O}$ $n=3$, given for only $30 \mathrm{~min})$. Results are given as mean \pm SEM. Basal values for insulin output were respectively: $5198 \pm 1702,2714$ $\pm 612,4218 \pm 575 \mu \mathrm{U} / \mathrm{min}$, and for blood glucose: $5.6 \pm 0.1,5.8 \pm$ $0.5,5.7 \pm 0.3 \mathrm{mmol} / 1$

L-noradrenaline was purchased from Fluka Laboratories (Buchs, Switzerland) in hydrochloride form and dissolved in water; L-adrenaline, also from Fluka Laboratories but in base form, was dissolved in water with an equimolar amount of hydrochloric acid. These solutions were distributed in tubes containing $1 \mathrm{mg}$ of catecholamine in $1 \mathrm{ml}$ solution and stored at $-40^{\circ} \mathrm{C}$. For each experiment the content of one tube was diluted in saline solution (sodium chloride $0.9 \%$ ) and infused with a Braun perfusor at a rate of $0.5 \mathrm{ml} / \mathrm{min}$. The syringe was wrapped in a ice-bag and kept out of the light. Chlorhydrate of $\mathrm{D}, \mathrm{L}$ propranolol was obtained from Avlon Laboratories (Enghien, France).

In the two experimental protocols, catecholamines (adrenaline and noradrenaline) were infused for $60 \mathrm{~min}$ at various doses, except for one set of experiments where the infusion lasted only $30 \mathrm{~min}$. In the experiments in normoglycaemic dogs, adrenaline was infused from time 0 at the concentrations of $0.01,0.5$ and $1 \mu \mathrm{g} \cdot \mathrm{kg}^{-1} \cdot \mathrm{min}^{-1}$. We have studied previously the effects of adrenaline infusion at $0.1 \mu \mathrm{g} \cdot \mathrm{kg}^{-1} \cdot \min ^{-1}$ [7]. Noradrenaline was used at 0.1 and $0.5 \mu \mathrm{g} \cdot \mathrm{kg}^{-1} \cdot \mathrm{min}^{-1}$. In the hyperglycaemic dogs, adrenaline and noradrenaline were infused from minutes $60-120$ at 1 and $2 \mu \mathrm{g}$. $\mathrm{kg}^{-1} \cdot \mathrm{min}^{-1}$. In another set of experiments propranolol was injected at $0.3 \mathrm{mg} / \mathrm{kg}$ IV $5 \mathrm{~min}$ before the infusion of noradrenaline at $2 \mu \mathrm{g} \cdot \mathrm{kg}^{-1} \cdot \mathrm{min}^{-1}$. In the control series, the animals received an infusion of saline solution (sodium chloride $0.9 \%$ ) for $60 \mathrm{~min}$. Adrenaline or noradrenaline were infused into a peripheral vein of one foreleg,
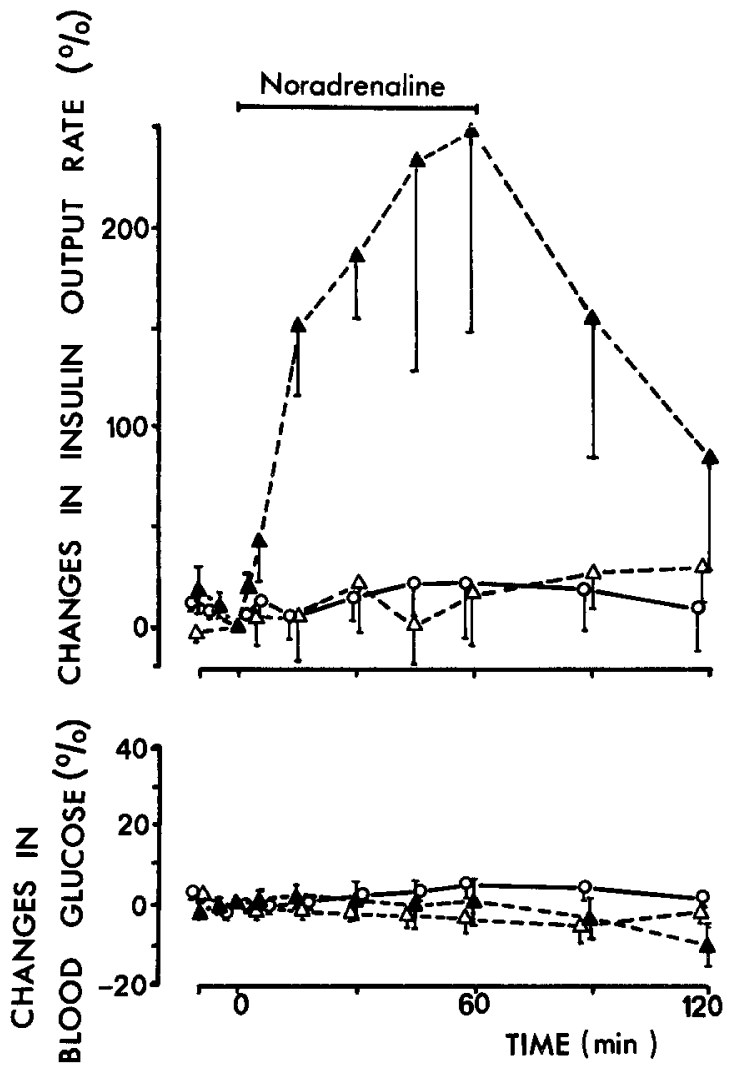

Fig. 2. Changes in plasma pancreaticoduodenal insulin output rate and in blood glucose in normoglycaemic dogs after noradrenaline infusion at the doses of $0.1 \mu \mathrm{g} \cdot \mathrm{kg}^{-1} \cdot \min ^{-1}(\Delta---\Delta, n=3)$ and $0.5 \mu \mathrm{g} \cdot \mathrm{kg}^{-1} \cdot \mathrm{min}^{-1}(\boldsymbol{\Delta}-\cdots--\mathbf{\Lambda}, n=5)$. A control group ( $\mathrm{O}-\mathrm{O}, n=$ 7) received sodium chloride $0.9 \%$ by IV infusion. Results are given as mean \pm SEM. Basal values for insulin output were respectively: 4876 $\pm 1610,4485 \pm 713,5129 \pm 1334 \mu \mathrm{U} / \mathrm{min}$ and for blood glucose: $5.1 \pm 0.4,5.0 \pm 0.2,5.5 \pm 0.3 \mathrm{mmol} / \mathrm{l}$

and glucose was infused into a peripheral vein of the other foreleg. Propranolol was injected into a peripheral vein before infusions of catecholamine.

\section{Statistical Analysis}

Blood glucose levels and insulin output rates are expressed as percentages of the basal values recorded at time 0 , just before the administration of catecholamines, and as mean \pm SEM. The results were submitted to analysis of variance using the multiple comparison test [17].

\section{Results}

\section{Normoglycaemic Dogs}

Adrenaline at the dose of $0.01 \mu \mathrm{g} \cdot \mathrm{kg}^{-1} \cdot \mathrm{min}^{-1} \mathrm{did}$ not induce any significant change in blood glucose and insulin secretion (Fig. 1). At $0.5 \mu \mathrm{g} \cdot \mathrm{kg}^{-1} \cdot \mathrm{min}^{-1}$, adrenaline produced a clear increase in blood glucose levels and in pancreaticoduodenal insulin output rate (Fig.1). 




Fig.3. Experiments performed in dogs made hyperglycaemic by an IV glucose infusion. Changes in plasma pancreaticoduodenal insulin output rate and in blood glucose after adrenaline infusions at the dose of $1 \mu \mathrm{g} \cdot \mathrm{kg}^{-1} \cdot \min ^{-1}(-, n=4)$ and $2 \mu \mathrm{g} \cdot \mathrm{kg}^{-1} \cdot \mathrm{min}^{-1}$ $(\mathrm{O}, n=5$ ). Results are given as mean \pm SEM. Basal values for insulin output were: $6348 \pm 1771$ and $5244 \pm 1196 \mu \mathrm{U} / \mathrm{min}$ and for blood glucose: $4.7 \pm 0.4$ and $5.1 \pm 0.2 \mathrm{mmol} / 1$, respectively

When administered at $1 \mu \mathrm{g} \cdot \mathrm{kg}^{-1} \cdot \mathrm{min}^{-1}$ for $30 \mathrm{~min}$, adrenaline also induced a rapid rise in blood glucose level and in pancreaticoduodenal insulin output (Fig.1). Although the adrenaline infusion was stopped at $30 \mathrm{~min}$, blood glucose levels remained elevated and were significantly higher than those induced by $0.5 \mu \mathrm{g} \cdot \mathrm{kg}^{-1} \cdot \mathrm{min}^{-1}$ at $60 \mathrm{~min}$. The increases in insulin output rate were, however, not significantly different for the two doses.

Noradrenaline at the dose of $0.1 \mu \mathrm{g} \cdot \mathrm{kg}^{-1} \cdot \mathrm{min}^{-1} \mathrm{did}$ not induce any significant change in blood glucose and insulin secretion (Fig. 2). At $0.5 \mu \mathrm{g} \cdot \mathrm{kg}^{-1} \cdot \mathrm{min}^{-1}$, this catecholamine did not significantly modify the blood glucose level but evoked an increase of insulin secretion which diminished when the infusion was stopped (Fig. 2).
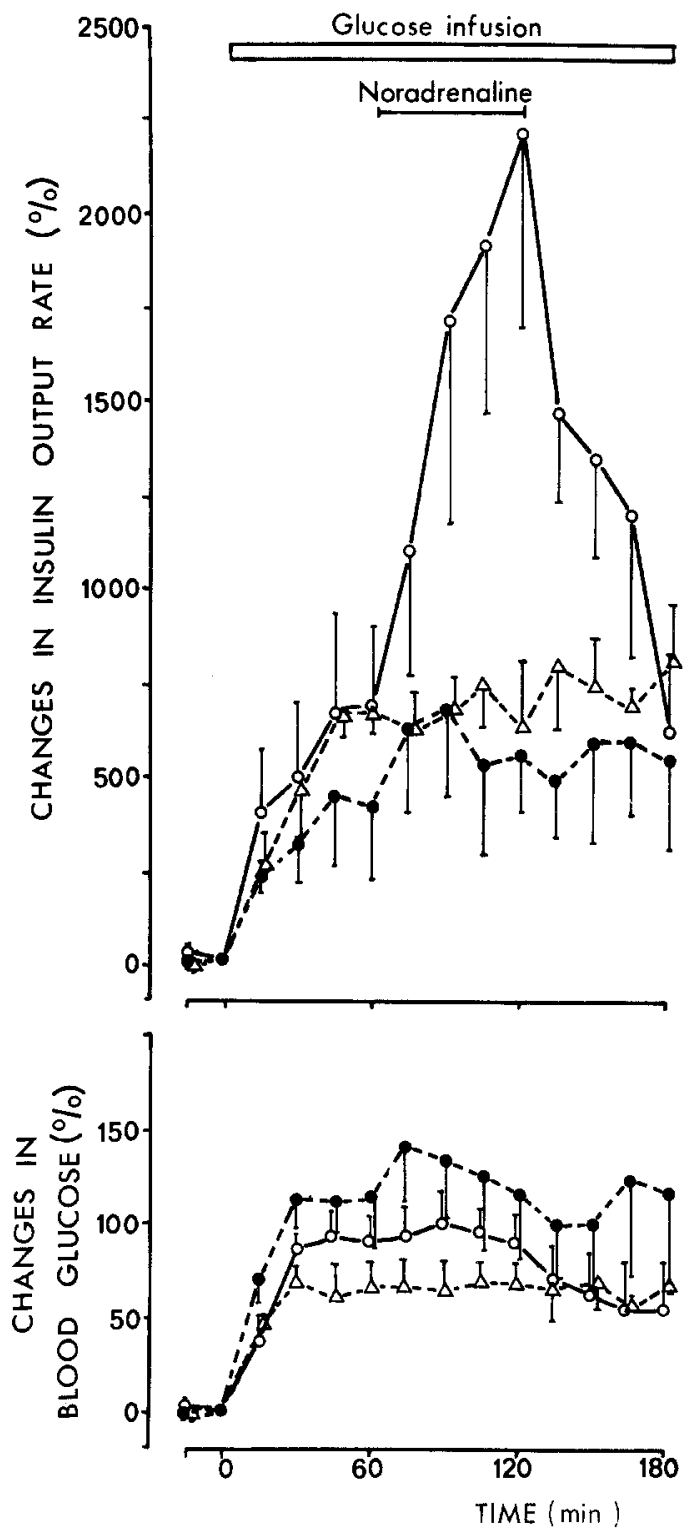

Fig.4. Experiments performed in dogs made hyperglycaemic by an IV glucose infusion. Changes in plasma pancreaticoduodenal insulin output rate and in blood glucose after noradrenaline infusions at the doses of $1 \mu \mathrm{g} \cdot \mathrm{kg}^{-1} \cdot \min ^{-1}(-, \quad n=3)$ and $2 \mu \mathrm{g} \cdot \mathrm{kg}^{-1} \cdot \mathrm{min}^{-1}$ $(\bigcirc-0, n=5)$. A control group $(\triangle \cdots-\triangle, n=4)$ received only a $3 \mathrm{~h}$ glucose infusion. Results are given as mean \pm SEM. Basal values for insulin output were: $5221 \pm 1472,6279 \pm 2208$ and $4991 \pm$ $966 \mu \mathrm{U} / \mathrm{min}$ and for blood glucose: $4.1 \pm 0.4,5.8 \pm 0.7$ and $4.9 \pm$ $0.3 \mathrm{mmol} / \mathrm{l}$, respectively

\section{Hyperglycaemic Dogs}

Experiments with adrenaline $\left(1 \mu \mathrm{g} \cdot \mathrm{kg}^{-1} \cdot \mathrm{min}^{-1}\right)$ (Fig. 3): During the first hour, the glucose infusion progressively increased the blood glucose level $(+72 \pm 21 \%$ at 30 min compared with basal value). Hyperglycaemia remained at a constant level until $60 \mathrm{~min}$. Pancreaticoduodenal insulin output rate rose to $+555 \pm 101 \%$ of the basal value at $60 \mathrm{~min}$. During the second hour, the adrenaline infusion at $1 \mu \mathrm{g} \cdot \mathrm{kg}^{-1} \cdot \mathrm{min}^{-1}$ reduced the insulin output rate to $+301 \pm 127 \%$ of basal at $120 \mathrm{~min}$; on the contrary the blood glucose level rose (from +72 


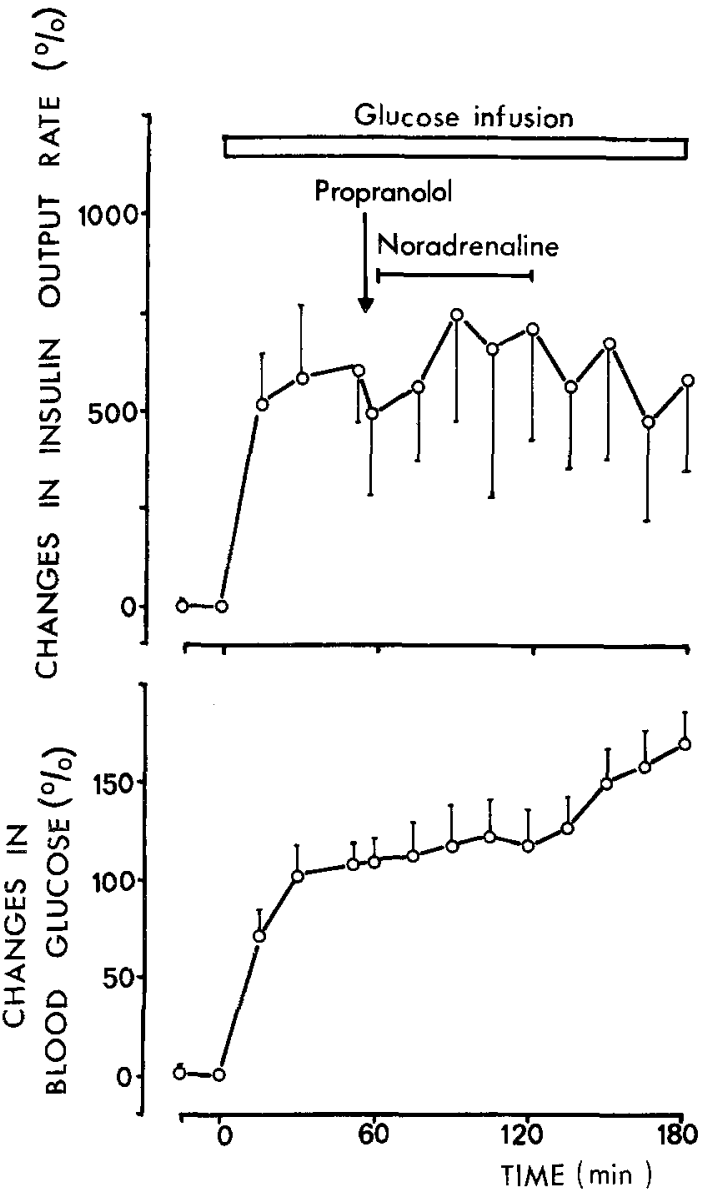

Fig.5. Experiments performed in dogs made hyperglycaemic by an IV glucose infusion. Effect of an IV injection of propranolol $(0.3 \mathrm{mg} / \mathrm{kg}$, $n=4$ ) on changes in plasma pancreaticoduodenal insulin output rate and in blood glucose induced by a noradrenaline infusion at the dose of $2 \mu \mathrm{g} \cdot \mathrm{kg}^{-1} \cdot \mathrm{min}^{-1}$. Results are given as mean $\pm \mathrm{SEM}$. Basal value for insulin output was $5451 \pm 1403 \mu \mathrm{U} / \mathrm{min}$ and for blood glucose $4.8 \pm 0.1 \mathrm{mmol} / 1$

\pm 21 to $+163 \pm 29 \%)$. On stopping the adrenaline infusion, the blood glucose level decreased and insulin output returned to values comparable to those before adrenaline infusion.

Experiments with adrenaline $\left(2 \mu \mathrm{g} \cdot \mathrm{kg}^{-1} \cdot \mathrm{min}^{-1}\right)$ (Fig. 3): The hyperglycaemia induced by glucose was further increased by the adrenaline infusion. At the same time the adrenaline infusion rapidly reduced the glucose-increased insulin output throughout the infusion period $(p<0.05)$. On stopping the adrenaline infusion, blood glucose levels decreased slightly and insulin output rate returned to values close to those obtained before catecholamine infusion.

Experiments with noradrenaline $\left(1 \mu \mathrm{g} \cdot \mathrm{kg}^{-1} \cdot \mathrm{min}^{-1}\right)$ (Fig. 4): At this dose, noradrenaline infusion did not significantly modify the hyperglycaemia and the increased insulin output rate induced by glucose.

Experiments with noradrenaline $\left(2 \mu \mathrm{g} \cdot \mathrm{kg}^{-1} \cdot \mathrm{min}^{-1}\right)$ (Fig. 4): The infusion of noradrenaline at $2 \mu \mathrm{g} \cdot \mathrm{kg}^{-1}$.

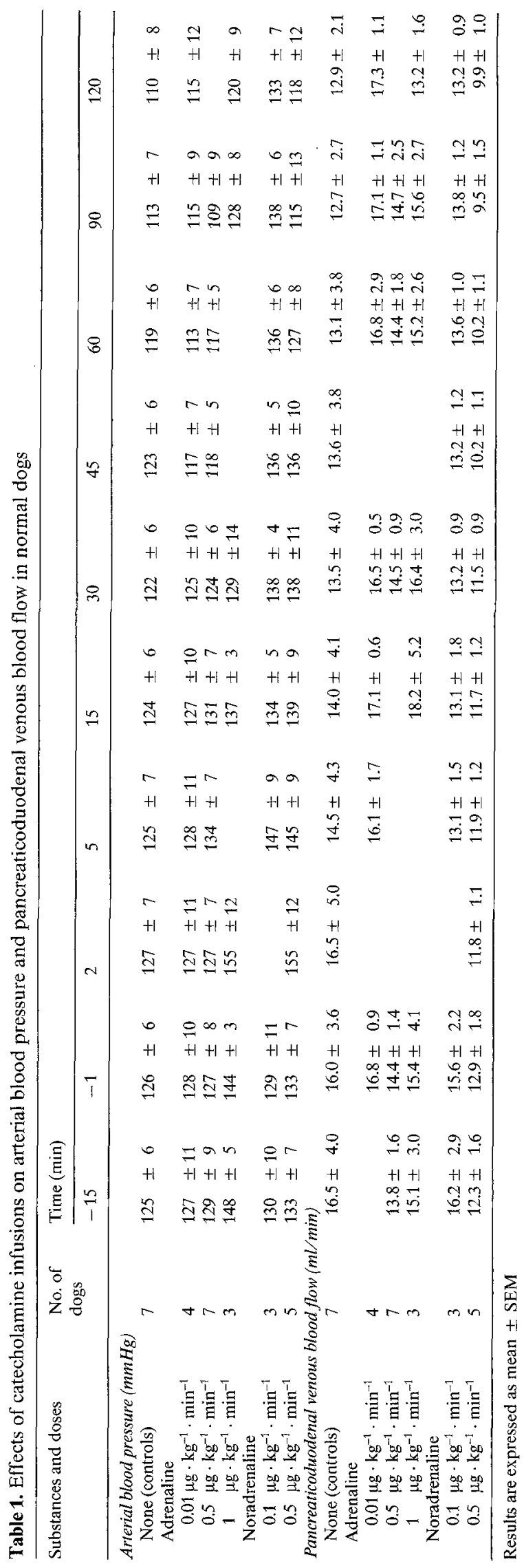


Table 2. Effects of catecholamine infusions on arterial blood pressure and pancreatico-duodenal venous blood flow in hyperglycaemic dogs

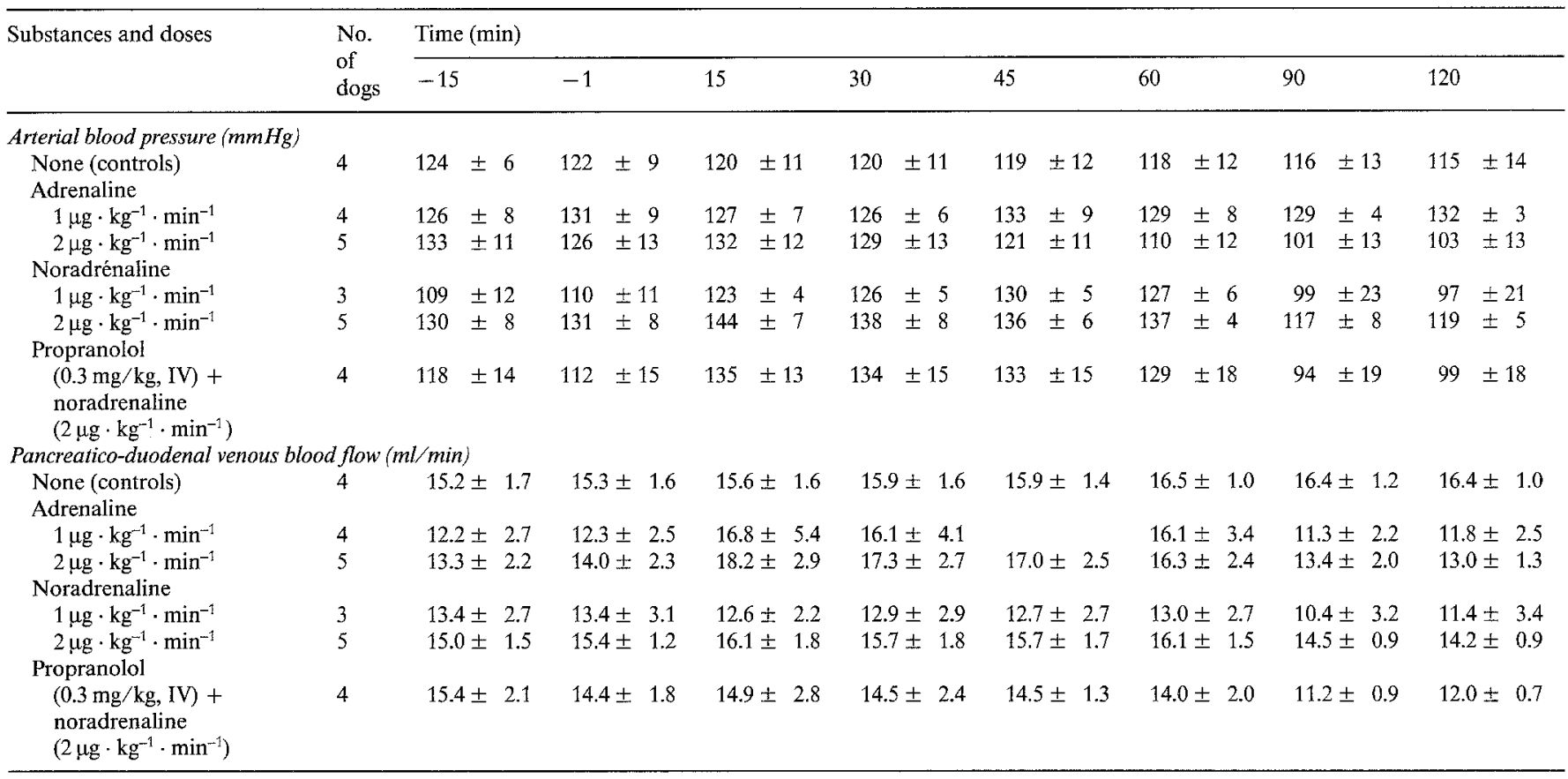

Results are expressed as mean \pm SEM

$\min ^{-1}$ induced a strong and significant stimulation of insulin secretion which rose from $+678 \pm 207$ to +2254 $\pm 540 \%$ of basal at $120 \mathrm{~min}(p<0.025)$, thus increasing threefold the hypersecretion of insulin already present. No significant change was observed in blood glucose level. On stopping noradrenaline infusion, insulin output rate fell rapidly and at $180 \mathrm{~min}$ returned to values close to those recorded before the catecholamine infusion. Hyperglycaemia showed a non-significant fall.

\section{Control Experiments}

The results obtained with the control group receiving glucose only for $3 \mathrm{~h}$ are shown in Figure 4.

Propranolol and noradrenaline (Fig. 5): Prior injection of propranolol suppressed the insulin stimulatory effect of the noradrenaline infusion. During this infusion the glucose-induced hyperglycaemia remained at the same level $(+110 \pm 10 \%$ at $60 \mathrm{~min}$ and $+118 \pm 17 \%$ at $120 \mathrm{~min}$ above basal value). Actual values were $10.1 \pm$ 0.7 and $10.6 \pm 1.0 \mathrm{mmol} / \mathrm{l}$, respectively.

\section{Effects on Blood Pressure and Pancreaticoduodenal Blood Flow}

The values of arterial blood pressure and pancreaticoduodenal venous blood flow obtained in normal and hyperglycaemic dogs after infusions of adrenaline and noradrenaline are listed in Tables 1 and 2. From these values it can be seen that the changes induced by the catecholamines are not great enough to account for changes in insulin secretion.

\section{Discussion}

When comparing our results with those obtained previously [7], it appears that adrenaline may cause stimulation, inhibition or no change in insulin secretion depending on the dose and experimental conditions. Similarly Wollheim and Sharp [14] showed that adrenaline could evoke inhibition or stimulation of insulin release in rat isolated islets depending on the experimental conditions.

Under the two experimental conditions described, adrenaline at $0.5,1$ and $2 \mu \mathrm{g} \cdot \mathrm{kg}^{-1} \cdot \mathrm{min}^{-1}$ induced glycogenolysis with hyperglycaemia in the normal anaesthetized dog. In the dogs which were initially normoglycaemic, the increase in blood glucose level was accompanied by a clear rise in insulin output. Nevertheless this increase in insulin output seemed to be less marked than the hyperinsulinaemia obtained in response to the same hyperglycaemia induced by glucose, although the difference was not significant (compare Fig. 1: adrenaline $1 \mu \mathrm{g} \cdot \mathrm{kg}^{-1} \cdot \mathrm{min}^{-1}$ and Fig. 4: controls with glucose infusion at $30 \mathrm{~min}$ ). In the animals whose insulin secretion was already stimulated by glucose the adrenaline infusion, although inducing an additional increase in blood glucose, reduced the hyperinsulinaemia produced previously. These experimental circumstances allowed the demonstration of the clear reduction in insulin secretion by adrenaline. Thus, in the presence of the same increment in blood glucose level, adrenaline exerted opposite effects on insulin secretion, depending on whether it is infused in animals whose insulin secretion has been previously stimulated by glucose or not. Under our experimental conditions no sig- 
nificant effect was noted with noradrenaline infused at the same doses.

The difference between the effects of adrenaline and noradrenaline on insulin secretion in the second experimental protocol is worthy of note (Figs. 3 and 4). It is generally accepted that both adrenaline and noradrenaline inhibit insulin secretion. This is not so in our experiments. Our results show that, under the same experimental conditions (stimulation by glucose and assay of insulin in the pancreaticoduodenal venous blood) and at the dose of $2 \mu \mathrm{g} \cdot \mathrm{kg}^{-1} \cdot \mathrm{min}^{-1}$, adrenaline and noradrenaline produce opposite effects on insulin secretion: the secretion is reduced by adrenaline but greatly increased by noradrenaline. This result may appear surprising but, as discussed below, the insulin stimulating effect recorded with the high dose of noradrenaline $\left(2 \mu \mathrm{g} \cdot \mathrm{kg}^{-1} \cdot \mathrm{min}^{-1}\right)$ may not be dependent on a direct effect on the pancreas. However, we never observed an inhibition of insulin secretion in response to noradrenaline in the present study. Iversen [4] using the isolated perfused dog pancreas in vitro, observed an inhibition of insulin secretion in response to noradrenaline, but this inhibition was much less marked $(-21 \%)$ than with adrenaline $(-64 \%)$.

It should be acknowledged that our experiments were performed on anaesthetized dogs. The insulin secretory response could in fact be influenced by anaesthetic agents, but as all the experiments on control as well as on treated dogs were carried out under the same conditions, anaesthesia cannot therefore explain the differences recorded.

It should be noted that, in our experimental conditions and at the doses used, propranolol did not reveal an $\alpha$-adrenergic inhibitory action of noradrenaline on insulin secretion. The fact that propranolol inhibits noradrenaline-induced insulin hypersecretion would support the hypothesis of $\beta$-adrenergic involvement in the insulin secretory effect of noradrenaline. However it may not be a direct action at the level of the $\beta$-adrenergic receptors of the insulin-secreting $B$ cell, but a more complex mechanism involving $\beta$-adrenergic receptors located at other levels. An alternative possibility is that noradrenaline, at the high dose of $2 \mu \mathrm{g} \cdot \mathrm{kg}^{-1} \cdot \mathrm{min}^{-1}$, may stimulate a central $\beta$-adrenergic pathway capable of mediating increased insulin secretion. Toivola et al. [13] found that the $\alpha$-adrenergic blocking drug, phentolamine, elevates peripheral insulin levels when placed in the hypothalamus of baboons. Furthermore, several authors have drawn attention to the modulation of insulin secretion by the hypothalamus. Micro-injection of noradrenaline into the ventromedial hypothalamic nucleus caused a rise in insulin levels in rabbits [11] while Steffens [12] reported that infusion of noradrenaline in the lateral hypothalamic area in the rat elicited insulin release during the whole period of noradrenaline infusion. More experiments are needed to elucidate the mechanism of the stimulatory action of noradrenaline on insulin secretion.
Acknowledgement. The expert technical assistance of Mr. R. Puech, Mr. Y.Gueorguieff, Mrs. M.F.Courty and Mr. R. Assié is gratefully acknowledged.

\section{References}

1. Alric R, Mariani MM, Loubatières A (1965) Importance de l'état des éléments figurés du sang et en particulier de celui des globules rouges sur les valeurs du glucose sanguin mesuré par l'auto-analyseur Technicon. Path Biol 13: 506-511

2. Coore HG, Randle PJ (1964) Regulation of insulin secretion studied with pieces of rabbit pancreas incubated in vitro. Biochem $\mathrm{J}$ 93: 66-78

3. Hales CN, Randle PJ (1963) Immunoassay of insulin with insulin antibody precipitate. Biochem J 88: 137-146

4. Iversen J (1973) Adrenergic receptors and the secretion of glucagon and insulin from the isolated, perfused canine pancreas. $J$ Clin Invest 52: 2102-2116

5. Loubatières A, Mariani MM, Chapal J (1970) Insulino-sécrétion étudiée sur le pancréas isolé et perfusé du rat. II. Action des catécholamines et des substances bloquant les récepteurs adrénergiques. Diabetologia 6:533-541

6. Loubatières-Mariani MM, Chapal J, Ribes G, Loubatières AL (1977) Discrepancies in the response of the insulin secreting cells of the dog and rat to different adrenergic stimulating agents. Acta Diabetol Latina 14: 144-155

7. Loubatières-Mariani MM, Ribes $G$, Blayac JP, Campo $P$ (1980) Insulin secretory effect of a low dose of adrenaline in the dog. Horm Metab Res 12:126-127

8. Malaisse WJ, Malaisse-Lagae F, Wright PH, Ashmore J (1967) Effects of adrenergic and cholinergic agents upon insulin secretion in vitro. Endocrinology 80: 975-978

9. Porte D Jr, Williams RH (1966) Inhibition of insulin release by norepinephrine in man. Science 152: 1248-1250

10. Porte D Jr, Graber AL, Kuzuya T, Williams RH (1966) The effects of epinephrine on immunoreactive insulin levels in man. J Clin Invest $45: 228-236$

11. Shimazu T, Ishikawa K (1981) Modulation by the hypothalamus of glucagon and insulin secretion in rabbits: studies with electrical and chemical stimulations. Endocrinology 108: 605-611

12. Steffens AB (1981) The modulatory effect of the hypothalamus on glucagon and insulin secretion in the rat. Diabetologia 20: 411-416

13. Toivola PTK, Gale CC, Goodner CJ, Werrbach JH (1972) Central $\alpha$-adrenergic regulation of growth hormone and insulin. Hormones 3: 193-213

14. Wollheim CB, Sharp GWG (1978) Stimulatory and inhibitory effects of epinephrine in islets $\mathrm{Ca}^{++}$uptake and insulin release. Diabetologia 15: 282 (Abstract)

15. Woods SC, Porte D Jr (1974) Neural control of the endocrine pancreas. Physiol Rev 54: 596-619

16. Wong KK, Symchowiez S, Staub MS, Tabachnick IIA (1967) The in vitro effect of catecholamines, diazoxide and theophylline on insulin release. Life Sci 6: 2285-2291

17. Zar JH (1974) Biostatistical analysis. Prentice Hall, Englewood Cliffs, New Jersey, USA, p 151

Received: 4 January 1982

and in revised form: 21 September 1982

Professor M. M. Loubatières-Mariani

Laboratoire de Pharmacologie

Institut de Biologie

Boulevard Henri IV

F-34060 Montpellier

France 